\title{
Analisis Kelayakan Pendirian Pusat Distribusi Provinsi (PDP) Jawa Barat
}

\author{
Eka Setiajatnika $^{\text {() }}$, Trida Gunadi ${ }^{2)}$ \\ Institut Manajemen Koperasi Indonesia ${ }^{1), 2)}$ \\ ekasetiajatnika@ikopin.ac.id \\ tridagunadi@gmail.com
}

\begin{abstract}
ABSTRAK
Tujuan penelitian ini adalah melakukan analisis kelayakan pendirian Pusat Distribusi Provinsi (PDP) di Kabupaten Purwakarta Jawa Barat yang dinilai dari aspek Potensi Sentra Produksi dan Permintaan Komoditi, Infrastruktur, Kondisi Sosial Ekonomi, Kondisi Lingkungan Hidup, Rencana Tata Ruang Wilayah, Regulasi, Lahan dan Pelaku Jasa Distribusi/ Logistik. Penelitian menggunakan metode Pairwise Comparison Matrix. Diperoleh kesimpulan bahwa, Kabupaten Purwakarta dianggap telah sesuai dan cukup memadai dalam penentuan kriteria sebagai Pusat Distribusi Provinsi.
\end{abstract}

Keyword: Pusat Distribusi Provinsi, Kelayakan PDP

\begin{abstract}
The purpose of this study was to analyze the feasibility of establishing a Provincial Distribution Center $(P D P)$ in Purwakarta Regency, West Java which was assessed from the aspects of the Potential of Production Centers and Commodity Demand, Infrastructure, Socio-Economic Conditions, Environmental Conditions, Regional Spatial Plans, Regulations, Land and Actors. Distribution / Logistics Services. This research used Pairwise Comparison Matrix method. It was concluded that, Purwakarta Regency was deemed appropriate and sufficient in determining the criteria as a Provincial Distribution Center.
\end{abstract}

Keyword: Provincial Distribution Center, PDP Feasibility

\section{PENDAHULUAN}

Menurut Peraturan Presiden No. 26 Tahun 2012 tentang Cetak Biru Pengembangan Sistem Logistik Nasional, salah satu kondisi logistik yang ingin dicapai adalah terwujudnya sistem logistik komoditas penggerak utama (key commoditie) yang mampu meningkatkan daya saing produk nasional baik di pasar domestik, pasar regional maupun di pasar global. Selain itu, sistem logistik komoditas penggerak utama ini ditujukan untuk menjamin ketersediaan barang, kemudahan mendapatkan barang dengan harga yang terjangkau dan stabil, serta mempersempit disparitas harga antar wilayah di Indonesia.

Adapun program yang direncanakan meliputi: (i) Pembangunan sistem logistic nasional melalui pengembangan jaringan distribusi penyangga baik ditingkat regional, provinsi maupun kabupaten/kota, penataan ulang dan revitalisasi sistem distribusi termasuk sistem distribusi antar pulau baik tata niaga, tata kelola, pelaku, dan sistem informasi, membangun dan merevitalisasi pasar tradisional baik prasarana, sarana, rantai pasok, maupun manajemen; (ii) Peningkatan ketersediaan pasokan nasional komoditas pokok dan strategis dan bahan baku yang masih diimpor; dan Peningkatan peran pemerintah daerah dalam penyediaan pasokan dan penyaluran komoditas pokok dan strategis; dan (iii) Penurunan disparitas harga komoditas pokok dan strategis baik antar waktu dan antar daerah melalui stabilisasi harga yang terjangkau secara merata dan pembangunan Terminal Agribisnis, Pusat Distribusi (distribution center), dan peningkatan pemanfaatan Sistem Resi Gudang.

Sejalan dengan Cetak Biru Pengembangan Sistem Logistik Nasional, Pemerintah Provinsi Jawa Barat telah menerbitkan Peraturan Daerah Provinsi Jawa Barat Nomor 1 Tahun 2020 tentang Pusat Distribusi Provinsi, dengan tujuan diantaranya menjaga dan mengendalikan stabilitas ketersediaan jumlah dan harga Barang Kebutuhan Pokok, memotong rantai 
dan menjamin kelancaran Distribusi dan Ketersediaan Barang Kebutuhan Pokok, meningkatkan fasilitas, sarana dan prasarana Perdagangan dan perlindungan konsumen di wilayah Provinsi Jawa Barat.

Pusat Distribusi Provinsi yang ada di jawa Barat akan menjadi penyangga bagi jaringan distribusi kabupaten/kota. Adapun kriteria penempatan PDP adalah jumlah penduduk, aksesibilitas, daerah konsumen (bukan penghasil dan bukan daerah produsen), dapat berfungsi sebagai kolektor (pusat konsolidasi) dan distributor, dan berpotensi untuk dikembangkan menjadi pusat perdagangan.

Berdasarkan latar belakang di atas, pemulis melakukan kegiatan Analisis Kelayakan Peentuan Pusat Distribusi Provinsi Jawa Barat dengan tujuan: menganalisis Kelayakan Pusat Distribusi Provinsi yang dinilai dari aspek Potensi Sentra Produksi dan Permintaan Komoditi (Supply-Demand), Infrastruktur, Kondisi Sosial Ekonomi, Kondisi Lingkungan Hidup, Rencana Tata Ruang Wilayah, Regulasi, Lahan dan Pelaku Jasa Distribusi/ Logistik.

\section{Pendekatan Konsep}

\section{Konsep Logistik}

Logistik atau manajemen logistik merupakan bagian dari proses supply chain yang merencanakan, mengimplementasikan, dan mengendalikan efisiensi dan efektivitas aliran dan penyimpanan barang, jasa, dan informasi terkait dari titik awal sampai ke titik konsumsi untuk memenuhi keperluan pelanggan (Council of Logistics Management (CLM), 1986). Gambar di bawah ini menunjukkan suatu sistem logistik secara sederhana.

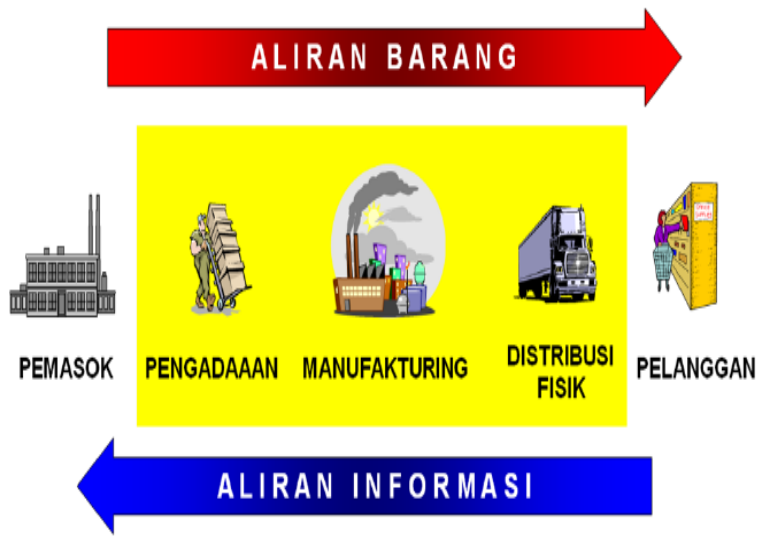

Gambar 1. Sistem Logistik

Pada prinsipnya, dalam suatu sistem logistik terdapat dua aliran utama. Aliran pertama adalah aliran barang dari pemasok, ke pabrik atau manufacturing, hingga ke pelanggan. Berlawanan dengan aliran barang, terdapat aliran informasi yang mengalir dari pelanggan, ke pabrik, hingga ke pemasok.

Selain memperhatikan aliran barang, manajemen logistik juga memperhatikan proses penyimpanan barang tersebut. Sebagai sebuah sistem, logistik terdiri atas beberapa subsistem atau komponenkomponen utama, yaitu Persediaan, Pergudangan, Transportasi, dan Sistem Informasi (Setijadi, 2009). Gambar berikut ini menunjukkan keterkaitan di antara komponen-komponen utama pembentuk sistem logistik tersebut.

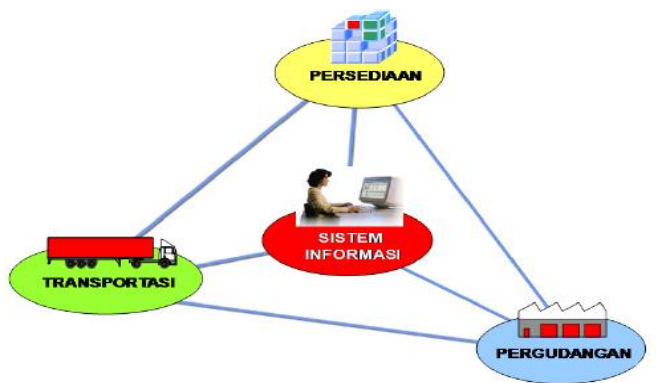

Gambar 2. Komponen-komponen Utama Pembentuk Sistem Logistik

Persediaan (inventory) adalah stok atau item-item yang digunakan untuk mendukung produksi (bahan baku dan barang setengah jadi), kegiatan-kegiatan (perawatan, perbaikan, dan operating supplies), dan pelayanan pelanggan (barang jadi dan suku cadang. Item-item tersebut dibeli untuk dijual kembali, mencakup barang jadi, barang setengah jadi, dan bahan baku (APICS Dictionary, 10th ed.). Persediaan harus diadakan dengan beberapa alasan, yaitu: 1) Persiapan kegiatan produksi dan penjualan; 2) Dukungan kegiatan perawatan, perbaikan, dan operasional; 3) Pertimbangan ekonomi skala (economies of scale); 4) Melindungi dari ketidakpastian permintaan; dan 5) Melindungi dari ketidakpastian pasokan.

Gudang merupakan fasilitas penting dalam sistem logistik yang mempunyai fungsi utama sebagai tempat penyimpanan barang atau produk. Barang atau produk disimpan sementara waktu sebelum digunakan atau dikirimkan ke tempat yang membutuhkan. Dalam sistem pergudangan terdapat tiga kegiatan utama penanganan barang, yaitu di bagian penerimaan, di dalam gudang, dan di bagian pengiriman. Penanganan barang tersebut membutuhkan berbagai metode dan peralatan. Fungsi gudang dapat dibedakan sebagai terminal konsolidasi, pusat distribusi, break-bulk operation, in-transit mixing, dan cross-dock operation. 
Dalam sistem logistik, transportasi berperan dalam perencanaan, penjadwalan, dan pengendalian aktivitas yang berkaitan dengan moda, vendor, dan pemindahan persediaan masuk dan keluar suatu organisasi. Pemilihan moda merupakan permasalahan yang penting.Pemilihan moda dilakukan dengan mempertimbangkan beberapa hal, seperti kondisi geografis, kapasitas, frekuensi, biaya (tarif), kapasitas, availabilitas, kualitas pelayanan dan reliabilitas (waktu pengiriman, variabilitas, reputasi, dll.). Secara umum, moda transportasi dibedakan atas kereta api, truk, transportasi air, transportasi udara, dan pipa.

Hal lain yang perlu diperhatikan dalam transportasi adalah mengenai local pickup and delivery serta longhaul movements. Perusahaan terkait biasanya memperhatikan perbedaan karakteristik jangkauan atau jarak ini dengan strategi transportasi yang berbeda. Untuk local pickup and delivery, perusahaan biasanya menggunakan armada sendiri. Untuk longhaul movements, biasanya menggunakan outsourching kepada penyedia jasa logistic (thirdparty logistics provider).

Dalam transportasi, pertimbangan ekonomis mencakup jarak, volume berat, kepadatan (density), dan bentuk (stowability). Pertambahan jarak, misalnya, akan berakibat bertambahnya biaya. Namun, pertambahan jarak tidak berbanding lurus dengan pertambahan biaya. Pertambahan biaya ini cenderung akan berkurang ketika jarak terus bertambah.

Sistem informasi merupakan saling keterkaitan perangkat keras dan perangkat lunak komputer dengan orang dan proses yang dirancang untuk pengumpulan, pemrosesan, dan diseminasi informasi untuk perencanaan, pengambilan keputusan, dan pengendalian (APICS Dictionary, 10th ed.)

Sistem informasi diperlukan untuk mengintegrasikan komponen-komponen dan kegiatan-kegiatan dalam sistem logistik. Efektivitas proses-proses dalam sistem logistic sangat dipengaruhi oleh kualitas informasi yang digunakan. Kualitas informasi dapat dilihat dari tiga aspek, yaitu: (1) ketersediaan informasi yang diperlukan untuk membuat keputusankeputusan terbaik, (2) keakuratan informasi, (3) efektivitas komunikasi. Aliran informasi dalam sistem logistik dapat dijabarkan pada gambar berikut ini.

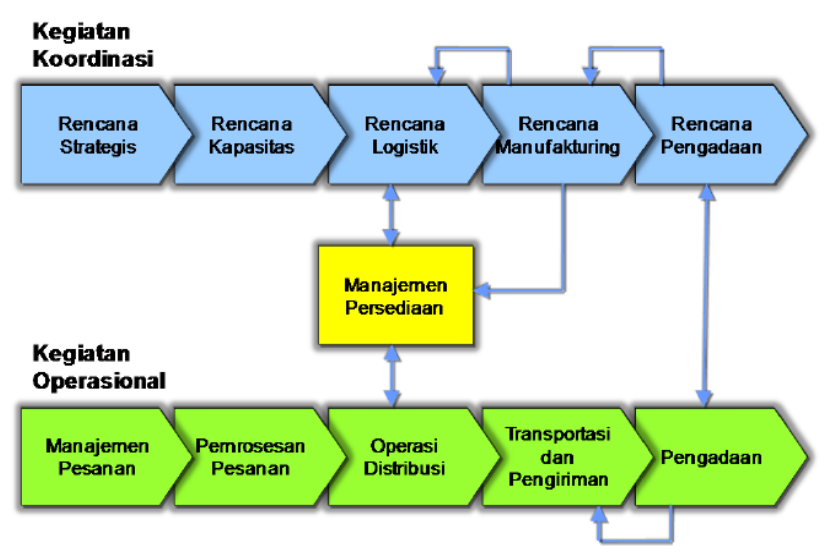

Sumber: Coyle, et al (2003)

Gambar 3 Aliran Informasi Logistik

Rantai pasok (supply chain) didefinisikan sebagai jaringan global yang digunakan untuk mengirimkan produk dan jasa dari bahan baku ke pelanggan akhir melalui aliran informasi, distribusi fisik, dan uang (APICS Dictionary, 11th ed.).

Sementara itu, manajemen rantai pasok (supply chain management/ SCM) di definisikan sebagai perancangan, perencanaan, eksekusi, pengendalian, dan pemantauan aktivitas-aktivitas rantai pasok dengan tujuan untuk menciptakan net value, membangun infrastruktur yang bersaing, leveraging worlwide logistics, melakukan sinkronisasi pasokan dengan permintaan, dan mengukur kinerja secara global (APICS). Definisi SCM yang lain adalah " $a$ network of organizations that are involved, through upstream and downstream linkages, in the different processes and activities that produce value in the form of products and services in the hands of the ultimate consumer" (Christopher, 1992).

Salah satu fenomena penting dalam rantai pasok adalah masalah amplifikasi permintaan (demand amplification) atau bullwhip effect. Ke arah hulu dalam rantai pasok, amplifikasi permintaan akan semakin meningkat pada setiap tingkatnya.

Amplifikasi ini disebabkan oleh adanya waktu tunda (delay time) dan ketidak-akuratan data dan informasi. Waktu tunda mencakup penundaan untuk operasi penciptaan nilai tambah (value-added) maupun penundaan karena idle.

Amplifikasi dan distorsi permintaan mengakibatkan tingkat produksi pada matarantai pabrik seringkali berfluktuasi jauh lebih besar dibandingkan yang terjadi pada tingkat penjualan aktual. Dengan adanya amplifikasi permintaan, pengaturan tingkat produksi atau pasokan menjadi suatu masalah sulit. Pada kondisi ini, produksi dan persediaan mengalami kelebihan (overshoot) dan kekurangan (undershoot) dari tingkat yang seharusnya. 


\section{Sistem Distribusi}

Distribusi adalah kegiatan yang berkaitan dengan pemindahan material, biasanya berupa barang (goods) atau suku cadang (parts), dari pabrik ke pelanggan, sedangkan transportasi berkaitan dengan fungsi perencanaan, penjadwalan, dan pengendalian aktivitas yang berkaitan dengan moda, vendor, dan pemindahan persediaan masuk dan keluar suatu organisasi (APICS).

Dalam sistem distribusi, berbagai pihak yang interdependent terlibat dalam proses penyampaian barang sehingga barang tersebut pada akhirnya dapat digunakan atau dikonsumsi oleh pelanggan atau masyarakat. Berbagai pihak tersebut membentuk suatu saluran distribusi (distribution channel) atau saluran pemasaran (marketing channel).

Kegiatan distribusi membutuhkan berbagai fasilitas, seperti depot, gudang (warehouse), pusat konsolidasi (consolidation centers), dan pusat distribusi (distribution centers). Suatu fasilitas distribusi bisa mempunyai beberapa fungsi. Gudang, misalnya, bias sekaligus berfungsi sekaligus sebagai pusat konsolidasi dan pusat distribusi. Berkaitan dengan fasilitas distribusi, beberapa hal perlu menjadi pertimbangan, antara lain penentuan. lokasi, kapasitas, peralatan, komoditas yang akan ditangani, wilayah yang akan dilayani, dan sebagainya.

\section{Pusat Distribusi}

Peraturan Menteri Perdagangan Republik Indonesia No. 48/M-DAG/PER/8/2013 BAB I Pasal 1 Nomor 3 disebutkan bahwa Pusat Distribusi adalah tempat yang berfungsi sebagai penyangga komoditas utama untuk menunjang kelancaran arus barang baik antar kabupaten/kota maupun antar provinsi untuk tujuan pasar dalam negeri dan/atau pasar luar negeri. Pusat Distribusi (PD) berperan menjembatani antara kepentingan petani/peternak/nelayan dan pasar (konsumen RT, konsumen non RT, industri pengolahan dan ekspor). Di sini PD berperan juga sebagai penyeimbang dan penyangga dari system rantai pasok yang ada. Di sini PD bertujuan untuk melayani kepentingan petani/peternak/ nelayan, konsumen dan pelaku sistem rantai pasok komoditas di wilayah rural dan juga perkotaan.

Pusat Distribusi (PD) berperan menjembatani antara kepentingan petani/peternak/nelayan dan pasar (konsumen RT, konsumen non RT, industri pengolahan dan ekspor). Di sini PD berperan juga sebagai penyeimbang dan penyangga dari system rantai pasok yang ada. Di sini PD bertujuan untuk melayani kepentingan petani/peternak/ nelayan, konsumen dan pelaku sistem rantai pasok komoditas di wilayah rural dan juga perkotaan.

Dalam rantai pasok dimana petani berposisi sebagai konsumen, PD berfungsi sebagai pemasok barang kebutuhan produksi pertanian/peternakan (saprotan, seperti benih, pupuk, pestisida) dan barang konsumsi masyarakat rural yang didapatkan langsung dari produsen pabrikan di dalam negeri maupun luar negeri (impor). Dengan demikian, di sini dapat dipangkas rantai distribusi barang kebutuhan bagi sektor rural yang akan berdampak pada keterjangkauan harga barang. Selain itu, Pusat Distribusi yang bekerja sama dengan bank dan badan asuransi juga menjalankan fungsi manajemen finansial bagi petani. Di sisi lain, PD juga berfungsi sebagai pusat konsolidasi hasil produksi yang dihasilkan petani/peternak/ nelayan sehingga mudah diserap pasar. PD ini pun juga terhubung dengan pasar grosir (wholesaler market) yang merupakan salah satu mata rantai sistem rantai pasok komoditas. Dengan demikian, PD merupakan institusi pelayanan bisnis komoditas pokok dan strategis untuk memberdayakan masyarakat petani/peternak/nelayan, penunjang industri pengolahan nasional, dan memberikan kontribusi kepada stakeholder lainnya. Dengan demikian, PD juga berperan sebagai instrumen sistem ekonomi nasional dengan fokus perhatian pada produsen (petani/peternak/nelayan) dengan memberikan keuntungan (nilai tambah) pada konsumen dan industri pengolahan.

Pusat Distribusi berperan juga sebagai penyeimbang dari sistem rantai pasok yang ada saat ini sehingga diharapkan harga pembelian di tingkat produsen akan menjadi meningkat dan harga penjualan di tingkat konsumen lebih stabil. Di sisi lain, petani/peternak/nelayan akan mendapatkan barang keperluan konsumsi dan kebutuhan saprotan/sapronak dengan harga yang lebih murah. Dengan demikian diharapkan petani/peternak/nelayan menjadi sejahtera, dan konsumen mendapatkan jaminan pasokan komoditas pokok dan strategis dengan harga yang stabil. Dengan adanya Pusat Distribusi ini, petani/peternak/nelayan akan bebas memilih kepada siapa hasil produksinya akan dijual, apakah kepada sistem yang ada atau kepada badan usaha yang baru ini. Badan usaha ini akan berfungsi untuk mengendalikan harga yang wajar bagi petani/peternak/nelayan sehingga secara tidak langsung akan membuat pengumpul dan pedagang barang konsumsi yang telah ada pun ikut memasang harga beli dan harga jual yang wajar. 
Pada prinsipnya, Pusat Distribusi (PD) sebagai suatu lembaga atau badan penyangga yang dapat menangani sistem rantai pasok komoditas pokok dan strategis yang diperlukan, memiliki aktivitas sebagai: 1) Penampung (Collector); 2) Pemasar (Marketer); 3) Grosir (Wholesaler); 4) Penyedia Jasa Logistik; 5) Pelayanan; 6) Pembinaan dan Kemitraan.

\section{Pusat Distribusi Regional/Provinsi}

Berdasarkan Peraturan Menteri Perdagangan Republik Indonesia Nomor: 48/MDAG/PER/8/2013 disebutkan bahwa Pusat Distribusi Regional adalah pusat distribusi yang berfungsi sebagai penyangga komoditas utama di beberapa kabupaten/kota yang memiliki jumlah penduduk, aksesibilitas, daerah konsumen, yang dapat bersifat kolektor, dan berpotensi untuk dikembangkan menjadi pusat perdagangan antar pulau.

Pusat Distribusi Regional (PDR) merupakan salah satu sub sistem jaringan yang pada dasarnya berfungsi sebagai penyokong bagi Pusat Distribusi Provinsi (PDP) yang berada di tiap propinsi dalam hal pemenuhan dan penyaluran kebutuhan maupun hasil produksi daerah. Pusat Distribusi Regional sendiri berada dalam naungan Kementerian Perdagangan.

\section{METODOLOGI PENELITIAN}

Analisis Kelayakan Pendirian Pusat Distribusi Provinsi (PDP) Jawa Barat dilakukan dengan analisis teknis dan analisis regulasi. Analisis teknis pendirian PDP dilakukan dengan mengidentifikasi faktor faktor : 1) Potensi Sentra Produksi dan Permintaan Komoditi; 2) Infrastruktur; 3) Kondisi Sosial Ekonomi; 4) Kondisi Lingkungan Hidup; 5) Rencana Tata Ruang Wilayah; 6) Lahan; dan 7) Pelaku Jasa Distribusi/ Logistik, Transportasi dan Pendanaan. Sedangkan Faktor regulasi mengidentifikasi peraturan perundangan yang mendukung mendirian PDP Jawa Barat.
Untuk menganalisis kelayakan Penetapan Pusat Distribusi Provinsi (PDP) Jawa Barat yang memenuhi kriteria digunakan Metode Pairwise Comparison Matrix. Metode Pairwise Comparison Matrix merupakan proses perbandingan nilai antar setiap faktor atau varians berpasangan yang menghasilkan bobot dari tiap varians atau faktor. Nilai faktor atau varians dalam membandingan antar faktor di dapatkan melalui perbandingan kepentingan antar tiap dua faktor. Dengan anggapan bahwa tiap faktor atau varians yang ada memiliki pengaruh atau bobot yang berbeda sesuai kepentingannya. Pada akhirnya faktor atau varians dengan nilai tertinggi memiliki bobot tertinggi.

Penentuan bobot dilakukan dengan membuat comparison matrix dari factors atau varians yang ada untuk dibandingkan dan diberi nilai sesuai kepentingan. Kemudian nilai total dari tiap faktor akan menjadi pembagi nilai faktor sendiri yang nantinya akan dijumlahkan dan menghasilkan bobot untuk tiap faktor. Setelah diperoleh bobot tiap faktor maka dilakukan penilaian terhadap variabel yang akan diuji. Variabel tersebut akan dinilai sesuai dengan kriteria atau batasan kelayakan dari tiap faktor yang akan dikalikan sesuai bobot dari tiap faktor.

Untuk menganalisis Potensi Permintaan Komoditi PDP dikukan pemetaan potensi sector ekonomi setiap Kabupaten/Kota di wilayah Jawa Barat menggunakan metode deskriptif kuantitatif dengan menggunakan instrumen Location Quotient (LQ). LQ merupakan instrumen untuk mengetahui peranan dan potensi sektor ekonomi di kabupaten/kota Provinsi Jawa Barat.

Gambaran lengkap tentang faktor-faktor, kriteria dan batasan mengukur kelayakan penentuan Pusat Distribusi Provinsi Jawa Barat dapat dilihat pada tabel 1 di bawah ini. 
Tabel 1 Faktor-faktor, Kriteria dan Batasan Kelayakan Pusat Distribusi Provinsi

\begin{tabular}{|c|c|c|c|}
\hline No. & Faktor & Kriteria & Batasan Kelayakan \\
\hline \multirow[t]{2}{*}{1} & \multirow{2}{*}{$\begin{array}{l}\text { Potensi Sentra } \\
\text { Produksi dan } \\
\text { Permintaan Komoditi }\end{array}$} & $\begin{array}{l}\text { a. Potensi Sentra Produksi } \\
\text { Komoditi }\end{array}$ & $\begin{array}{l}\text { Memiliki potensi sentra-sentra produksi dari kab./kota di } \\
\text { Provinsi Jawa Barat. (Undang-Undang No.18 Tahun } 2012 \\
\text { tentang Pangan) }\end{array}$ \\
\hline & & b. Potensi Permintaan Komoditi & $\begin{array}{l}\text { Memiliki potensi permintaan bahan dari kab./kota di } \\
\text { Provinsi Jawa Barat. }\end{array}$ \\
\hline \multirow{7}{*}{2} & \multirow{7}{*}{$\begin{array}{l}\text { Infrastruktur. } \\
\text { (Undang-Undang } \\
\text { No.7 Tahun } 2014 \\
\text { tentang } \\
\text { Perdagangan, Pasal } \\
13 \& 14 \text { ) }\end{array}$} & \multirow{4}{*}{ a. Aksesibilitas } & - Aksesibilitas berdasarkan kondisi jalan \\
\hline & & & - Berada pada lokasi dekat pelabuhan \\
\hline & & & - Berada pada lokasi dekat terminal angkutan \\
\hline & & & - Berada pada lokasi dekat Jalur Kereta Api \\
\hline & & b. Tersedianya Tenaga Listrik & $\begin{array}{l}\text { Terdapat jaringan listrik yang memadai yang sesuai } \\
\text { dengan kapasitas pusat distribusi. }\end{array}$ \\
\hline & & $\begin{array}{l}\text { c. Ketersediaan Sarana Teknologi } \\
\text { Informasi dan Komunikasi } \\
\text { (TIK) }\end{array}$ & $\begin{array}{l}\text { Terdapat saran TIK yang memadai, seperti jaringan } \\
\text { telepon, jaringan nirkabel, kantor pos, ketersediaan tower } \\
\text { provider/BTS dan lain-lain. }\end{array}$ \\
\hline & & $\begin{array}{l}\text { d. Ketersediaan Sistem } \\
\text { Pengelolaan Air dan } \\
\text { pengolahan limbah pasar } \\
\text { (persampahan) }\end{array}$ & $\begin{array}{l}\text { - Terdapat ketersediaan air yang memadai dan sistem } \\
\text { pengolahan air yang baik guna menunjang } \\
\text { keberlangsungan aktivitas pusat distribusi. } \\
\text { - Dekat dengan lokasi TPA. } \\
\end{array}$ \\
\hline \multirow{5}{*}{3} & \multirow{5}{*}{$\begin{array}{l}\text { Kondisi Sosial } \\
\text { Ekonomi. (Perpres } \\
\text { No.71/2015 } \\
\text { Penetapan dan } \\
\text { Penyimpanan Barang } \\
\text { Kebutuhan Pokok dan } \\
\text { Barang Penting) } \\
\end{array}$} & a. Kondisi Sosial Kemasyarakatan & Indeks Pembangunan Masyarakat Jawa Barat \\
\hline & & Keoiatan & $\begin{array}{l}\text { - Terdapat aktivitas perdagangan rutin antar wilayah } \\
\text { untuk komoditi. }\end{array}$ \\
\hline & & Perdagangan & $\begin{array}{l}\text { Tidak Terdapat aktivitas perdagangan rutin antar } \\
\text { wilayah untuk komoditi }\end{array}$ \\
\hline & & c. Potensi Konflik Sosial & $\begin{array}{l}\text { Sejarah terjadinya konflik sosial di sekitar lokasi sangat } \\
\text { minim. }\end{array}$ \\
\hline & & d. Kondisi Ekonomi & Pendapatan Perkapita \\
\hline \multirow{3}{*}{4} & \multirow{3}{*}{$\begin{array}{l}\text { Kondisi Lingkungan } \\
\text { Hidup. (Perpres } \\
\text { No.26/2012) }\end{array}$} & a. Bukan kawasan rawan bencana & Tidak berada dalam kawasan rawan bencana \\
\hline & & b. Bukan Kawasan Lindung & Tidak berada dalam kawasan lindung \\
\hline & & c. Bukan Kawasan Cagar Budaya & Tidak berada dalam kawasan Cagar Budaya \\
\hline \multirow[t]{2}{*}{5} & \multirow[t]{2}{*}{$\begin{array}{l}\text { Rencana Tata Ruang } \\
\text { Wilayah. }\end{array}$} & a. Perda RTRW & $\begin{array}{l}\text { Berdasarkan Peraturan Presiden No. } 26 \text { Tahun } 2012 \text { tentang } \\
\text { Cetak Biru Pengembangan Sistem Logistik Nasional yakni } \\
\text { terdapat Perda RTRW Provinsi yang mengatur pusat } \\
\text { distribusi dalam konsep kawasan. }\end{array}$ \\
\hline & & b. Potensi Status Khusus & $\begin{array}{l}\text { Berada dalam kawasan khusus yang memiliki keistimewaan } \\
\text { tertentu dari segi kebijakan insentif. }\end{array}$ \\
\hline \multirow[b]{2}{*}{6} & \multirow{2}{*}{$\begin{array}{l}\text { Regulasi. } \\
\text { (UU Nomor } 23 \\
2014 \text { Tentang } \\
\text { Pemerintahan } \\
\text { Daerah) }\end{array}$} & a. RPJMD & $\begin{array}{l}\text { Pembangunan Pusat Distribusi telah ditetapkan dalam } \\
\text { RPJMD }\end{array}$ \\
\hline & & $\begin{array}{l}\text { b. Ketersediaan Peraturan Pusat } \\
\text { Distribusi (Perda No.1/2020) }\end{array}$ & $\begin{array}{l}\text { Telah terdapat Peraturan Pusat Distribusi yang telah } \\
\text { ditetapkan oleh otoritas setempat. }\end{array}$ \\
\hline \multirow{3}{*}{7} & \multirow{3}{*}{ Lahan } & a. Luasan Minimum & $\begin{array}{l}\text { Berdasarkan Peraturan Menteri Perdagangan Republik } \\
\text { Indonesia Nomor 48/M-Dag/PER 8-2013 tentang pedoman } \\
\text { dan pengelolaan sarana distribusi perdagangan pasal } 10 \text { dan } \\
11 \text { butir a dikatakan bahwa luasan minimum bagi PDP } \\
\text { adalah } 10.000 \mathrm{~m}^{2}\end{array}$ \\
\hline & & b. Legalitas & $\begin{array}{l}\text { Sesuai dengan Peraturan Menteri Perdagangan Republik } \\
\text { Indonesia Nomor 48/M-Dag/PER 8-2013 tentang pedoman } \\
\text { dan pengelolaan sarana distribusi perdagangan pasal } 10 \text { dan } \\
11 \text { butir b dikatakan bahwa kepemilikan lahan pendirian } \\
\text { PDP haruslah dibuktikan dengan dokumen yang sah, yaitu } \\
\text { sertifikat kepemilikan tanah yang dikeluarkan oleh Badan } \\
\text { Pertanahan Nasional. }\end{array}$ \\
\hline & & c. Peluang Perluasan Lahan & $\begin{array}{l}\text { Terdapat lahan untuk perluasan sampai dengan atau lebih } \\
\text { dari } 10 \text { ha. }\end{array}$ \\
\hline \multirow{3}{*}{8} & \multirow{3}{*}{$\begin{array}{l}\text { Pelaku Jasa } \\
\text { Distribusi/ Logistik, } \\
\text { Transportasi dan } \\
\text { Pendanaan. } \\
\text { (Permendag 22/2016) }\end{array}$} & a. Ketersediaan Distributor & Terdapat distributor yang telah beraktifitas di sekitar lokasi. \\
\hline & & $\begin{array}{l}\text { b. Pelaku Jasa } \\
\text { Transportasi/Freight } \\
\text { Forwarding }\end{array}$ & $\begin{array}{l}\text { Terdapat pelaku jasa transportasi/freight forwading yang } \\
\text { telah beraktifitas di sekitar lokasi. }\end{array}$ \\
\hline & & c. Ketersediaan Jasa Pendanaan & $\begin{array}{l}\text { Terdapat jasa pendanaan yang telah beraktifitas di sekitar } \\
\text { lokasi. }\end{array}$ \\
\hline
\end{tabular}




\section{Hasil Analisis}

Dalam menentukan kelayakan penetapan Pusat Distribusi Provinsi (PDP) Jawa Barat menggunakan Metode Pairwise Comparison Matrix, Pengukuran dilakukan skoring antar wilayah pengembangan dengan faktor-faktor yang memengaruhi kelayakan PDP. Berikut disajikan faktor yang memengaruhi kelayakan penetapan Pusat Distribusi berserta bobot skoringnya.

Tabel 2. Faktor-faktor yang Memengaruhi Penetapan Pusat Distribusi Provinsi Beserta Bobotnya

\begin{tabular}{clc}
\hline Kode & \multicolumn{1}{c}{ Faktor } & Bobot \\
\hline A & $\begin{array}{l}\text { Potensi Sentra Produksi dan } \\
\text { Permintaan Komoditi }\end{array}$ & $12 \%$ \\
\hline B & Infrastruktur & $10 \%$ \\
\hline C & Kondisi Sosial Ekonomi & $6 \%$ \\
\hline D & Kondisi Lingkungan Hidup & $5 \%$ \\
\hline E & $\begin{array}{l}\text { Rencana Tata Ruang } \\
\text { Wilayah }\end{array}$ & $17 \%$ \\
\hline F & Regulasi & $28 \%$ \\
\hline G & Lahan & $14 \%$ \\
\hline H & $\begin{array}{l}\text { Pelaku Jasa Distribusi/ } \\
\text { Logistik, Transportasi dan } \\
\text { Pendanaan }\end{array}$ & $8 \%$ \\
\hline Suber Hasil Olah Data
\end{tabular}

Sumber: Hasil Olah Data

Analisis dilakukan dengan kriteria-kriteria dan batas kelayakan sebagai berikut.

1) Memiliki potensi akan potensi-potensi sentra produksi dan permintaan komoditas.

2) Infrastruktur yang memadai berupa memiliki aksesbilitas atau keterjangkauan ke Pelabuhan dan jalur kereta api, tersedia tenaga listrik, terdapat ketersediaan tower provider dan jaringan, dan terdapat TPA.

3) Kondisi ekonomi dan social mendukung baik dilihat dari indeks pembangunan manusia dan nilai PDRB.

4) Ketersesuaian dengan rencana tata ruang setempat yaitu RTRW Provinsi Jawa Barat dan memiliki potensi sesuai dengan arah pengembangan.

5) Terdapat regulasi dan rencana yang menaungi peraturan Pusat Distribusi Provinsi oleh otoritas setempat.

6) Lahan pembangunan PDP harus legal secara sah, memiliki luas minimal 1 ha, dan memiliki peluang untuk diperluas.

7) Terdapat distributor, pelaku jasa transportasi, dan jasa pendanaan yang beraktifas di wilayah setempat.

Setelah dilakukan analisis, maka di peroleh hasil skoring wilayah pengembangan (WP) di Jawabarat dalam penetapan PDP sebagai berikut.
Tabel 3 Hasil Skoring Wilayah Pengembangan Penetapan Pusat Distribusi Provinsi Jawa Barat

\begin{tabular}{lc}
\hline Wilayah Pengembangan & $\begin{array}{c}\text { Komoditas } \\
\text { Basis }\end{array}$ \\
\hline Bandung Raya & 0.70 \\
Bodebek & 0.72 \\
Sukabumi dan sekitarnya & 0.62 \\
Purwasuka & $\mathbf{0 . 9 5}$ \\
Ciayumajakuning & 0.88 \\
Priangan Timur & 0.81 \\
\hline
\end{tabular}

Sumber : Hasil Olah Data

Nilai skor tertinggi penetapan Pusat Distribusi Provinsi (PDP) Jawa Barat, diperoleh bahwa Wilayah Pengembangan (WP) Purwasuka (skor $=0,95$ ) merupakan wilayah yang paling memenuhi kelayakan dalam penetapan Pusat Distribusi Provinsi (PDP) Jawa Barat.

\section{Potensi Sentra Produksi Dan Permintaan Komoditi}

Salah satu faktor dalam menetapkan pusat distribusi provinsi adalah wilayah tersebut memiliki potensi untuk menjadi sentra produksi dan dapat memenuhi permintaan komoditas di wilayah sekitar.

Sentra adalah suatu pusat kegiatan produksi khusus suatu komoditi di suatu wilayah tertentu yang ditunjang dengan kegiatan ekonomi baik mikro, kecil, maupun menengah. Sentra produksi dapat dikembangkan di suatu wilayah saat wilayah tersebut memenuhi kriteria ketersediaan sumberdaya lahan dan manusia yang mumpuni, agroklimat yang sesuai dengan komoditas unggulan, prasarana dan infrastruktur yang memadai, dan keberlanjutan lingkungan hidup. Oleh karena itu, jika sebuah wilayah memenuhi kriteria dapat dikatakan memiliki potensi sentra produksi.

Permintaan akan komoditas terjadi saat konsumen memiliki keinginan dan kemampuan untuk membeli komoditas tersebut karena kebutuhan. Permintaan komoditas yang melebihi supply komoditas mengakibatkan kelangkaan. Oleh karena itu, permintaan dengan harga memiliki hubungan yang bersifat dua arah. Berdasarkan hasil analisis di dapatkan bahwa tiap wilayah pengembangan di Provinsi Jawa Barat memiliki basis yang berbeda. Menggunakan metode analisis Location Quotient di peroleh hasil sebagai dibawah berikut. 
Tabel 4 Komoditas Basis Wilayah Pengembangan Provinsi Jawa Barat Tahun 2019

\begin{tabular}{ll}
\hline \multicolumn{1}{c}{$\begin{array}{c}\text { Wilayah } \\
\text { Pengembangan }\end{array}$} & \multicolumn{1}{c}{ Komoditas Basis } \\
\hline Bodebek & Sapi dan Ayam pedaging \\
\hline Bandung Raya & $\begin{array}{l}\text { Kentang, Daging Sapi dan Ayam } \\
\text { kampung }\end{array}$ \\
\hline Purwasuka & Padi \\
\hline Sukabumi Dan Sekitar & $\begin{array}{l}\text { Padi, Ayam kampung, Ayam } \\
\text { pedaging dan Ikan air umum } \\
\text { daratan }\end{array}$ \\
\hline Ciayumajakuning & $\begin{array}{l}\text { Padi, Ikan tangkap di laut dan Ikan } \\
\text { air umum daratan }\end{array}$ \\
\hline Priangan Timur & $\begin{array}{l}\text { Kentang, Ayam kampung dan } \\
\text { Ayam pedaging }\end{array}$ \\
\hline Sumber : Hasil Olah Data
\end{tabular}

Sumber : Hasil Olah Data

Berdasarkan tabel diatas di ketahui bahwa terdapat tiga wilayah pengembangan yang memiliki komoditas basis padi yaitu WP Purwasuka, WP Sukabumi dan sekitar, dan WP Ciayumajakuning. Oleh karena itu dapat dikatakan pada Wilayah Pengembangan tersebut dapat dikatakan memiliki produksi padi setara berasa yang tinggi. Selain itu dalam sisi permintaan berdasarkan data publikasi Badan Pusat Statistik tahun 2019 beras merupakan bahan makanan memiliki nilai konsumsi rata-rata per kapita seminggu tertinggi di Provinsi Jawa Barat yaitu sebesar 1,5277 $\mathrm{kg}$ di bandingkan bahan makanan lainnya. Dengan demikian WP Purwasuka, WP Sukabumi dan sekitar, dan WP Ciayumajakuning dapat dianggap sesuai kriteria penentuan PDP.

\section{Kondisi Infrastruktur}

Infrastruktur merupakan struktur dan fasilitas untuk menunjang dan mendukung standar kehidupan. Infrastruktur memilki fungsi sabagi pendorong pengembangan masyarakat, pengembangan ekonomi kota dan wilayah, membentuk struktur kota, dan dapat meningkatkan kondisi lingkungan. Oleh karena itu, keberadaan infrastruktur yang memadai dapat meningkatkan value suatu kawasan.

Dari gambar 4 dapat diketahui bahwa pada rencana infrastruktur lebih banyak tersebar di bagian utara yang merupakan WP Bandung Raya, WP Purwasuka, dan WP Bodebek di banding bagian selatan.

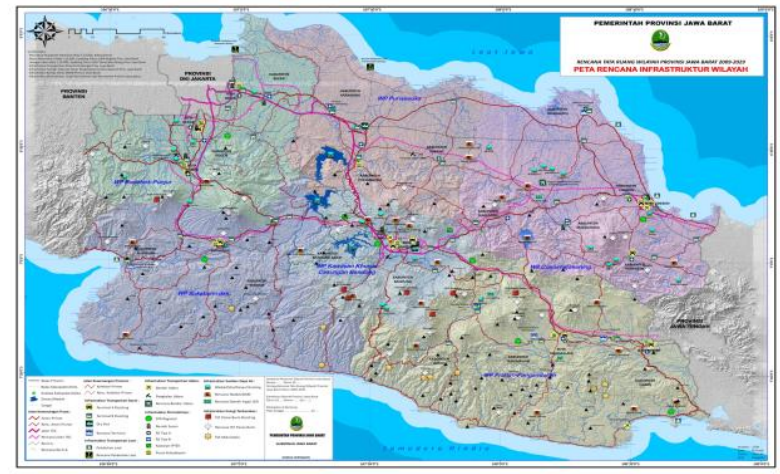

Gambar 4. Peta Rencana Infrastruktur Wilayah Jawa Barat

Aksesbilitas menjadi salah satu kriteria dalam penetapan PDP dimana semakin tinggi aksesbilitas akan berpengaruh positif.

Tabel 5 Jumlah Pelabuhan dan Stasiun Kereta Api berdasarkan Wialayah Pengembangan Provinsi Jawa Barat

\begin{tabular}{lcc}
\hline Wilayah Pengembangan & Pelabuhan & $\begin{array}{c}\text { Stasiun } \\
\text { Kereta Api }\end{array}$ \\
\hline Bodebek & 0 & 25 \\
Bandung Raya & 0 & 26 \\
Purwasuka & 1 & 19 \\
Sukabumi Dan Sekitar & 0 & 15 \\
Ciayumajakuning & 1 & 20 \\
Priangan Timur & 1 & 20
\end{tabular}

Sumber: Data Dinas Perhubungan Provinsi Jawa Barat,2020

Pada tabel diatas dapat diketahui bahwa keenam wilayah pengembangan memiliki stasiun kereta api dan hanya tiga wilayah pengembangan yang memiliki Pelabuhan dimana menjadi poin tambahan terhadap ketersediaan infrastruktur pendukung Pusat Distribusi Provinsi (PDP) di Jawa Barat.

\section{Kondisi Sosial Ekonomi}

Kondisi sosial ekonomi di Provinsi Jawa Barat dapat dikatakan cukup beragam. Di tahun 2019 PDRB atas harga berlaku di Jawa Barat mengalami peningkatan di bandingkan tahun sebelumnya yaitu 2.125,16 triliun rupiah. Berikut di bawah ini di sajikan data PDRB atas harga berlaku menurut kabupaten/kota di Jawa Barat.

Indeks Pembangunan Manusia Provinsi Jawa Barat di tahun 2019 adalah 72,03 dimana meningkat daripada tahun-tahun sebelumnya. Kota Bandung memiliki IPM tertinggi yaitu sebesar 81,56 diikuti oleh Kota Bekasi, Kota Depok, dan Kota Cimahi. Selain itu, Kabupaten Cianjur memiliki IPM terendah yaitu sebesar 65,38. 


\section{Kondisi Lingkungan Hidup}

Setiap Pembangunan memiliki hubungan erat dengan lingkungan sekitarnya. Mempertimbangkan kondisi lingkungan dapat menimalisir dampak akan ketidak seimbangan lingkungan hdiup dimasa depan. Menurut Keputusan Presiden Republik Indonesia nomor 32 tahun 1990, Kawasan Lindung adalah kawasan yang ditetapkan dengan fungsi utama melindungi kelestarian Lingkungan Hidup yang mencakup sumber alam, sumber daya buatan dan nilai sejarah serta budaya bangsa guna kepentingan Pembangunan berkelanjutan. Oleh karena itu untuk menjaga dan mendorong pembangunan keberlanjutan pusat distribusi tidak boleh berada dalam kawasan lindung. Berikut di sajikan gambar peta kawasan lindung di Provinsi Jawa Barat.

Batasan kelayakan kondisi lingkungan hidup penentuan Pusat Distribusi Provinsi menurut Perpres Nomor 26 tahun 2012, antara lain: Tidak berada dalam kawasan rawan bencana, Tidak berada dalam kawasan lindung dan Tidak berada dalam kawasan Cagar Budaya. Kawasan lindung mayoritas berada pada bagian selatan dan tengah Provinsi Jawa Barat yang meliputi WP Bodebek tertuma wilayah bogor, WP Priangan Timur, dan WP Bandung Raya.

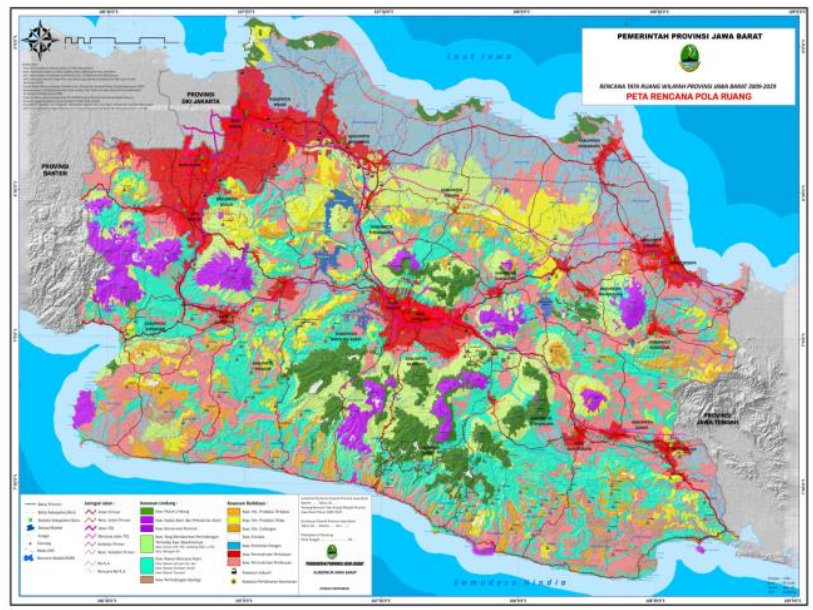

Sumber: Rencana Tata Ruang Wilayah Provinsi Jawa Barat 2009-2029

Gambar 5 Peta Rencana Pola Ruang Wilayah Jawa Barat

Dari peta pada gambar 5 dapat diketahui bahwa kawasan lindung mayoritas berada pada bagian selatan dan tengah Provinsi Jawa Barat yang meliputi WP Bodebek tertuma wilayah bogor, WP Priangan Timur, dan WP Bandung Raya.

Selain itu penetapan pusat distribusi tidak berada di kawasan rawan bencana. Hal ini di karena kan untuk keamanan dan dapat menimalisir baik kerugian maupun korban jiwa. Jawa Barat merupakan salah satu provinsi di Indonesia yangrawan bencana. Oleh karena itu perlu di hindari penetapan di wilayah yang rawan akan bencana.

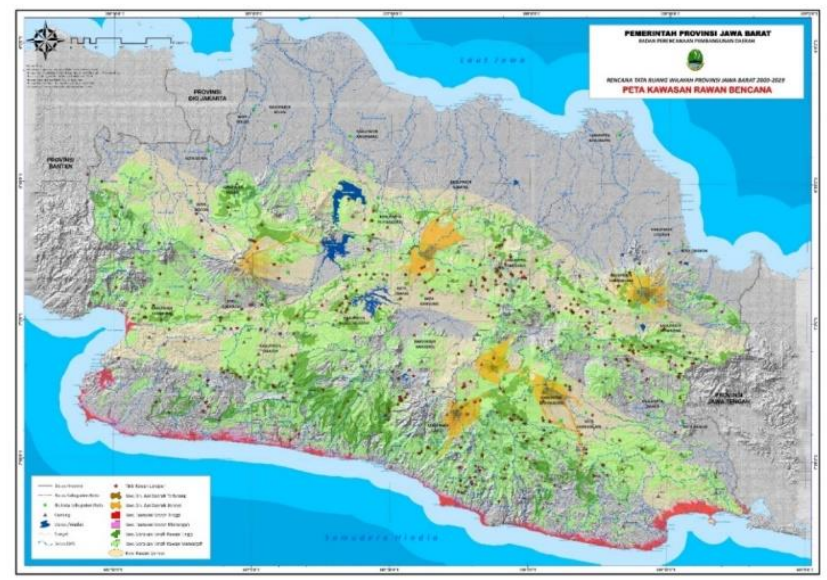

Sumber: Rencana Tata Ruang Wilayah Provinsi Jawa Barat 2009-2029

Gambar 6 Peta Kawasan Rawan Bencana Wilayah Jawa Barat

Pada peta diatas dapat diketahui bahwa bagian selatan Provinsi Jawa Barat meliputi WP Priangan Timur dan WP sukabumi dan sekitarnya memiliki kerawanan bencana yang sangat tinggi. Selain itu untuk bagian tengah Provinsi Jawa Barat meliputi WP Bandung Raya dan WP Ciayumajakuning merupakan kawasan rawan bencana terutama gempa dan gunung berapi. Untuk WP Bodebek Sebagian merupakan kawasan rawan bencana di wilayah bogor dan untuk WP Purwasuka Sebagian merupakan kawasan rawan bencana di Kabupaten Purwakarta dan bagian selatan Kabupaten Subang. Kondiri tersebut (rawan bencana) menjadi pertimbangan dalam penetapan lokasi pembangunan Gudang Pusat Distribusi (PDP) di Jawa Barat.

\section{Tata Ruang Wilayah}

Rencana Tata Ruang Wilayah atau lebih dikenal dengan RTRW adalah arahan kebijakan dan strategi pemanfaatan ruang untuk jangka Panjang berbentuk dokumen spasial. RTRW berisi pedoman-pedoman mengenai penyususunan rencana pembangunan di suatu wilayah. RTRW merupakan dokumen spasial dasar dalam setiap pemanfaatan ruang. Oleh karena itu, setiap pembangunan di suatu wilayah harus mengacu kepada RTRW setempat dalam kasus ini adalah RRTW Nasional dan RTRW Provinsi Jawa Barat. 
Batasan kriteria kelayakan Pusat distribusi Provinsi dari faktor Rencana Tata Ruang Wilayah, antara lain:

- Peraturan Presiden No. 26 Tahun 2012 tentang Cetak Biru Pengembangan Sistem Logistik Nasional yakni terdapat Perda RTRW Provinsi yang mengatur pusat distribusi dalam konsep kawasan.

- Berada dalam kawasan khusus yang memiliki keistimewaan tertentu dari segi kebijakan insentif

Dalam RTRW pemanfaatan ruang dilakukan melalui rencana pengembangan masing-masing Wilayah Pengembangan (WP). Wilayah Pengembangan sendiri di tetapkan sesuai dengan target pencapaian penataan ruang dan arah pengembangan ekonomi. Mengacu pada arah pengembangan kegiatan ekonomi WP Bodebek lebih berfokus pada pengembangan komoditas unggulan yaotu padi, jagung, dan kedelai serta meningkatan investasi padat modal.

WP Purwasuka memiliki arah pengembangan peningkatan akan produksi dan distribusi pangan serta unggul pada industry pengolahan namun tetap mempertahankan pangan. Hal tersebut terjadi mengingat WP Purwasuka merupakan ruang pangan Jawa Barat dan terletak antara dua metropolitan yang rawan akan konversi lahan pertanian. Begitu pula WP Ciayumajakuning dan WP Sukabumi sekitarnya memiliki arah pengembangan peningkatan produksi dan distribusi pangan.

WP Priangan Timur memilik arah pengembangan untuk meningkatkan produktivatas sektor yang ada yaitu sektor pertanian, perikanan, perkebunan, pariwisata serta meningkatkan industry pengolahan yang dapat meningkatkan SDA yang ada. Terakhir WP Bandung Raya memiliki arah pengembangan untuk mengendalikan pencemaran lingkungan hidup serta di fokuskan pada perdangangan dan jasa.

Oleh karena itu, pada kasus ini WP Purwasuka, WP Ciayumajakuning, dan WP Sukabumi dan sekitarnya memiliki arah pengembangan yang sesuai dengan menetapkan Pusat Distribusi Provinsi (PDP) di Jawa Barat.

\section{Pelaku Jasa Distribusi/ Logistik, Transportasi dan Pendanaan}

Sesuai dengan Peraturan Menteri Perdagangan Republik Indonesia Nomor 22/M-DAG/PER/3/2016 tentang Ketentuan Umum Distribusi Barang, distribusi adalah kegiatan menyalurkan barang secara langsung dan tidak langsung kepada konsumen dan distributor adalah pelaku usaha distribusi yang bertindak atas nama sendiri dan atas nama penunujukan produsen atau supplier atau importir berdasarkan perjanjian untuk melakukan kegiatan pemasaran barang. Dengan demikian keberadaan ditributor penting dalam penetapan pusat distribusi provinsi begitu pula dengan penyedia jasa transportasi untuk mempermudah kegiatan distribusi.

\section{Kondisi Lahan}

Lahan merupakan salah satu aspek penting dimana lahan yang akan digunakan harus memiliki legalitas kepemilikan dan sesuai dengan peruntukan lahan dari RTRW Provinsi Jawa Barat. Oleh karena itu, sama hal nya seperti aspek lingkungan hidup dimana lahan tersebut tidak boleh berada di kawasan lindung. Selain itu, lahan yang akan digunakan memiliki luang perluasan dan pengembangan mengingat diharapkan PDP bisa berkembang terus. Berdasarkan analisis di peroleh bahwa lahan di WP Purwasuka tepatnya berlokasi di Kecamatan Campaka paling memenuhi kriteria kelayakan Pusat Distribusi Provinsi.

Berdasarkan Peraturan Menteri Perdagangan Republik Indonesia Nomor 48/M-Dag/PER 8-2013 tentang pedoman dan pengelolaan sarana distribusi perdagangan pasal 10 dan 11 butir a dikatakan bahwa luasan minimum bagi Pusat Distribusi Provinsi adalah $10.000 \mathrm{~m} 2$. Kemudian, syarat lain sesuai dengan Peraturan Menteri Perdagangan Republik Indonesia Nomor 48/M-Dag/PER 8-2013 tentang pedoman dan pengelolaan sarana distribusi perdagangan pasal 10 dan 11 butir $\mathrm{b}$ dikatakan bahwa kepemilikan lahan pendirian PDP haruslah dibuktikan dengan dokumen yang sah, yaitu sertifikat kepemilikan tanah yang dikeluarkan oleh Badan Pertanahan Nasional.

\section{Regulasi}

Aspek regulasi kelayakan pendirian PDP Jawa Barat mengacu kepada peraturan perundangan yang ada (Undang-Undang, Peraturan Pemerintah, Peraturan Presiden, Peraturan Kementerian, Peraturan Daerah). Berikut ini peraturan perundangan sebagai rujukan hukum pendirian PDP Jawa Barat sebagai berikut

a. Undang-Undang No.18 Tahun 2012 tentang Pangan

b. Undang-Undang No.23 Tahun 2014 tentang Pemerintahan Daerah

c. Undang Undang RI Nomor 7 Tahun 2014 tentang Perdagangan

d. Peraturan Presiden RI Nomor 26 Tahun 2012 tentang Cetak Biru Pengembangan Sistem Logistik Nasional

e. Peraturan Presiden No.71 Tahun 2015 tentang Penetapan dan Penyimpanan Barang Kebutuhan Pokok dan Barang Penting 
f. Peraturan Daerah Nomor 1 tahun 2020 tentang Pusat Distribusi Provinsi

Pada pasal 2 ayat a, bahwa Pengaturan Pusat Distribusi Provinsi, bertujuan menjaga dan mengendalikan stabilitas ketersediaan jumlah dan harga Barang Kebutuhan Pokok. Pusat Distribusi Provinsi berfungsi: distribusi; stabilisasi; dan kontribusi (pasal 5). Selanjutnya pasal 6, bahwa Distribusi utama, berfungsi untuk melakukan pasokan dan distribusi barang kebutuhan pokok, dengan volume yang cukup, kualitas baik, dan harga yang stabil.

\section{SIMPULAN DAN SARAN}

\section{Simpulan}

Hasil Analisisi Kelayakan Penentuan Pusat Distribusi Provinsi dapat dismpulkan sebagai berikut:

1. Potensi Sentra Produksi Dan Permintaan Komoditi. Bahwa, WP Purwasuka, WP Sukabumi dan sekitar, dan WP Ciayumajakuning dapat dianggap sesuai kriteria penentuan Pusat Distribusi Provinsi, karena WP memiliki potensi untuk menjadi sentra produksi dan dapat memenuhi permintaan komoditas di wilayah sekitar.

2. Rencana infrastruktur lebih banyak tersebar di bagian utara yang merupakan WP Bandung Raya, WP Purwasuka, dan WP Bodebek di banding bagian selatan. PDP Jawa Barat Kabupaten Purwakarta berpotensi Infrastruktur di wilayah PDP Kecamatan Campaka Kabupaten Purwakarta cukup memadai, baik infrastruktur transportasi laut (pelabuhan), maupun infrastruktur transportasi darat (jalan raya).

3. Kondisi Sosial Ekonomi. Kondisi sosial ekonomi di Provinsi Jawa Barat untuk tahun 2019 digambarkan sebagai berikut: PDRB 2019 sebesar Rp 2.125,16 triliun rupiah; IPM sebesar 72,03; Jumlah Penduduk 49.316.710 jiwa; Pertumbuhan ekonomi sebesar 5,07\%; dan Gini Ratio 0.398 .

4. Batasan kelayakan kondisi lingkungan hidup penentuan Pusat Distribusi Provinsi menurut Perpres Nomor 26 tahun 2012, antara lain: Tidak berada dalam kawasan rawan bencana, Tidak berada dalam kawasan lindung dan Tidak berada dalam kawasan Cagar Budaya. Lokasi Pusat Distribusi Provinsi berada di kecamatan Campaka Kabupaten Purwakarta sesuai dengan kriteria tersebut (Perpres no.26/2012)
5. Tata Ruang Wilayah, bahwa WP Purwasuka, WP Ciayumajakuning, dan WP Sukabumi dan sekitarnya memiliki arah pengembangan yang sesuai dengan menetapkan Pusat Distribusi Provinsi (PDP) di Jawa Barat.

6. Pelaku Jasa Distribusi/ Logistik, Transportasi dan Pendanaan. Sesuai dengan Peraturan Menteri Perdagangan Republik Indonesia Nomor 22/MDAG/PER/3/2016 tentang Ketentuan Umum Distribusi Barang.

7. Kondisi Lahan telah sesuai dengan Peraturan Menteri Perdagangan Republik Indonesia Nomor 48/M-Dag/PER 8-2013 tentang pedoman dan pengelolaan sarana distribusi perdagangan (pasal 10 dan 11 butir a dan b).

8. Regulasi. Sesuai dengan peraturan perundangan yang berlaku (UU No.18/2012, UU No.23/2014, UU No.7/2014, Peraturan Presiden RI Nomor 26 Tahun 2012, Peraturan Presiden No.71 Tahun 2015 dan Peraturan Daerah Nomor 1 tahun 2020 tentang Pusat Distribusi Provinsi

\section{Saran}

1. Aksesibilitas dari/ke lokasi PDP Jawa Barat di Kecamatan Campaka Kabupaten Purwakarta perlu didukung dengan infrastruktur transportasi darat (jalan raya) yang memadai dari aspek kelas jalan dan kondisinya.

2. Peningkatan kompetensi sumber daya manusia (SDM) perlu segera dilakukan dalam masa pembangunan PDP Jawa Barat di Kecamatan Campaka Kabupaten Purwakarta, sehingga dapat diharapkan PDP dapat segera beroperasi secara baik segera setelah pembangunan PDP tersebut selesai.

\section{DAFTAR PUSTAKA}

APICS Dictionary, 10th ed.

Coyle, J.L., Gibson, B.J., Novack, R.A., Bardi, E.J. (2003). Supply Chain Management: A Logistics Perspective. Cengage Learning.

Christopher, M. (1992). Logistics \& Supply Chain Management. Prentice-Hall.

Rahayuningrum, N., Anugrah, I.S., Friyanto, S., Santoso, A.S., Hariyadi, Erlan, R., Sitepu, I.C., Acep. (2007). Kajian Pengembangan Pusat Distribusi Regional Produk Agro. Pusat Penelitian dan Pengembangan Perdagangan Dalam Negeri, Badan Penelitian dan Pengembangan Perdagangan, Departemen Perdagangan. 
Setijadi (2009). Handout Sistem Logistik. Universitas Widyatama Bandung

\section{Peraturan Perundangan}

Peraturan Presiden Nomor 26 Tahun 2012 tentang Cetak Biru Pengembangan Sistem

Logistik Nasional.

Peraturan Menteri Keuangan Republik Indonesia Nomor 125/PMK.06/2011 tentang

Pengelolaan Barang Milik Negara yang Berasal dari Dana Dekonsentrasi dan Dana Tugas Pembantuan sebelum Tahun Anggaran 2011.

Peraturan Menteri Keuangan Republik Indonesia Nomor 96/PMK.06/2007 tentang Tata Cara Pelaksanaan Penggunaan, Pemanfaaatan, Penghapusan, dan Pemindahtanganan Barang Milik Negara.

Peraturan Menteri Perdagangan Republik Indonesia Nomor 86/M-DAG/PER/12/2012 tentang Petunjuk Teknis Penggunaan Dana Alokasi Khusus (DAK) Bidang Sarana Perdagangan Tahun Anggaran 2013.

Peraturan Menteri Perdagangan Republik Indonesia Nomor 48/M-DAG/PER/8/2013 tentang Pedoman Pembangunan dan Pengelolaan Sarana Distribusi Perdagangan.

Kementerian Perdagangan Republik Indonesia (2012). Laporan Akhir Panduan Pembangunan dan Pengembangan Pusat Distribusi Regional (PDR). 